\title{
Influence of Saturation Magnetization of a Master Disk on Its Perpendicular Magnetic Contact Duplication Characteristics
}

\author{
T. Murata, A. Izumi, T. Komine, and R. Sugita \\ Ibaraki Univ., 4-12-1 Nakanarusawa-cho, Hitachi-shi, Ibaraki-ken 316-8511, Japan
}

The influence of saturation magnetization of a master disk on its perpendicular magnetic contact duplication characteristics was investigated by using the two-dimensional finite element method. An investigation of bit printing (where the duplication field is applied in a direction perpendicular to the disk plane) and edge printing (where the duplication field is applied in an in-plane direction), revealed the following points. In bit printing, the influence of saturation magnetization of a master disk on perpendicular duplication characteristics is very small when the duplication field is nearly equal to the coercivity of the slave ( $4 \mathrm{kOe})$, which is the optimum field. On the other hand, in edge printing, the duplication characteristics are better for high saturation magnetization of a master disk than for low saturation magnetization. The cause of this difference in the influence of saturation magnetization of a master disk is the demagnetizing field of the master. In bit printing, the influence of saturation magnetization of a master disk is small because of the high demagnetizing field coefficient, while in edge printing, the influence of saturation magnetization of a master disk is large because of the low demagnetizing field coefficient.

Key words: magnetic contact duplication, perpendicular magnetic recording media, servo signal, servo writing

\section{マスターディスクの飽和磁化が垂直磁気転写特性に及ぼす影響}

\author{
村田剛史・和泉昭彦・小峰啓史・杉田龍二 \\ 茨城大学工学部, 茨城県日立市中成沢町 4-12-1（率316-8511）
}

\section{1. はじめに}

ハードディスクの高密度化, 大容量化が進み, 垂直磁気記録方式 を採用したハードディスクの実用化が始まっている. また, サーボ 信号を高速に書き込む方法である磁気転写法 1)を，垂直記録媒体 へ適用す心゙く研究が行われている 2) 5). 磁気転写法は, マスターデ イスクの磁性層が転写時に印加する磁束を吸い込む現象を利用し て, マスターディスクの凹凸パターンをスレーブディスクに磁化 の変化として転写するものである. 転写する際には, マスターディ スクからの強、磁場が必要であるため, マスターディスクが有す る磁性層の飽和磁化が転写特性に大きな影響を及ぼすと考えられ る. しかし, 磁気転写に用いるマスターディスクの飽和磁化が垂直 磁気転写特性に及ぼす影響は，まだ明らかになっていない．また， 垂直記録媒体への磁気転写法としては, 転写磁場を媒体膜面の垂 直方向に印加するビット転写と, 面内方向に印加するエッジ転写 2) の 2 通りがあり，いずれの方法においても垂直磁気転写が可能で ある. しかし，両転写法の優位性等はまだ明らかになっているとは 言えない. そこで本研究では, 2 次元有限要素法を用いて, マスタ 一ディスクの飽和磁化が垂直磁気転写特性に及ぼす影響を，両転 写法について比較しつつ検討を行つた.

\section{2. シミュレーション方法}

ビット転写においては，一方向に初期磁化したスレーブディス クにパターニングされた磁性層を有するマスターディスクを接触 させ, 初期磁化と反対向きに転写磁場を印加する. これにより, マ スター磁性層接触部では磁場が強くなるため初期磁化が反転され, 一方, 非接触部では磁場が弱くなり初期磁化が保存される. その結 果, マスターディスクのパターンがスレーブディスクに転写され る. エッジ転写においては, 消磁状態のスレーブディスクにマスタ

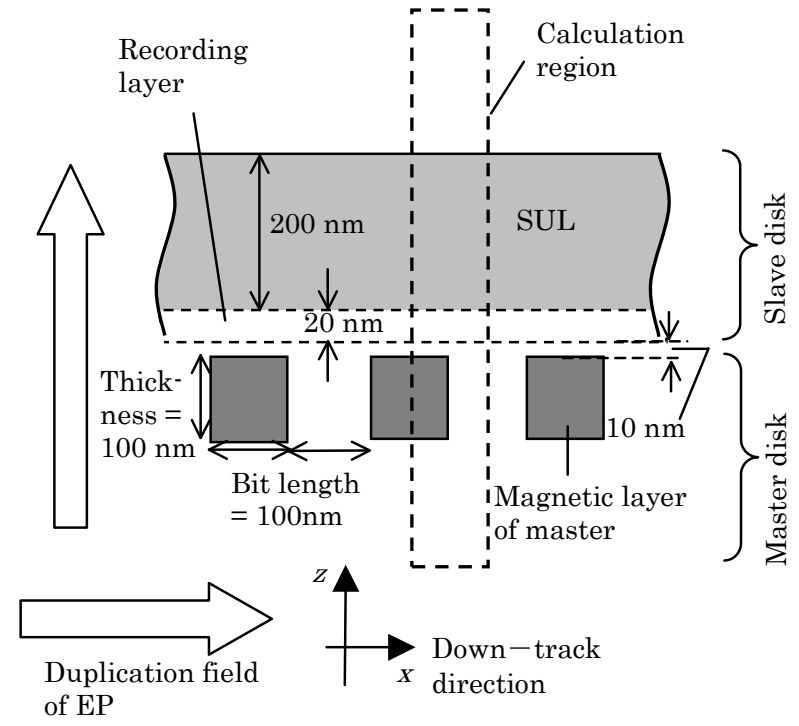

Fig. 1 Simulation model.

一ディスクを接触させ, 媒体膜面内方向に転写磁場を印加する. す ると, マスター磁生層エッジ部で強い垂直磁場成分が現れ, これに より, スレーブディスクが垂直方向に磁化される. なお本研究で は, 垂直磁気転写特性における第 1 次近似として, 両転写 法における磁場及び磁化の垂直成分の夕を考慮する. 両転写法 における記録層表面の磁場分布を求め, 磁場の垂直成分分布及び Fig. 2 に示されるスレーブディスクにおける垂直磁化膜の垂直方 向ヒステリシス曲線 4) から, 転写された垂直方向磁化分布を求め た.

シミュレーションに用いたモデルを Fig. 1 に示寸. また, マスタ 一ディスク及びスレーブディスクの磁気特性及び膜厚 $\delta$ Table 
1 に示寸. マスターディスクのビット長を $100 \mathrm{~nm}$ とした. 垂直磁化膜は，マスターディスクの磁性層から $10 \mathrm{~nm}$ 離れ て SUL に接して配置した. なお系の対称性より, Fig. 1 の 破線で囲まれた, マスター磁性層を $1 / 2$ 含む領域を計算領 域とした。ビット転写では転写磁場を $z$ 方向に, エッジ転写では $\boldsymbol{x}$ 方向に印加した. マスター磁生層の飽和磁化 $M_{\mathrm{s}}$ を 490, 1000, 1500, $1900 \mathrm{emu} / \mathrm{cm}^{3}$ と変えた. マスター磁性層及び SUL ともに ヒステリシス曲線は飽和を考慮して折孔線で近似し，いずれも透 磁率を 100 とした. また, マスター磁性層それぞれの $M_{\mathrm{s}}$ における 飽和磁場 $H_{\mathrm{s}}$ は, 62, 127, 190, $240 \mathrm{Oe}, \mathrm{SUL} の H_{\mathrm{s}}$ は $102 \mathrm{Oe}$ である.

次に, マスター磁性層中心位置における磁束密度, 反磁 場, 磁化及び反磁場係数を求めた. 反磁場は, マスター磁 性層の B-H 曲線を用いて計算した。

Table 1 Magnetic properties and thickness of master and slave disks.

\begin{tabular}{|c|c|c|c|c|}
\hline & $\begin{array}{c}M_{\mathrm{s}} \\
{\left[\mathrm{emu} / \mathrm{cm}^{3}\right]}\end{array}$ & $\begin{array}{c}H_{\mathrm{c}} \\
{[\mathrm{kOe}]}\end{array}$ & $\begin{array}{c}\delta \\
{[\mathrm{nm}]}\end{array}$ \\
\hline \multicolumn{2}{|c|}{ Master disk } & $490 \sim 1900$ & 0 & 100 \\
\hline \multirow{2}{*}{$\begin{array}{c}\text { Slave } \\
\text { disk }\end{array}$} & $\begin{array}{c}\text { Recording } \\
\text { layer }\end{array}$ & 500 & 4 & 20 \\
\cline { 2 - 5 } & SUL & 800 & 0 & 200 \\
\hline
\end{tabular}

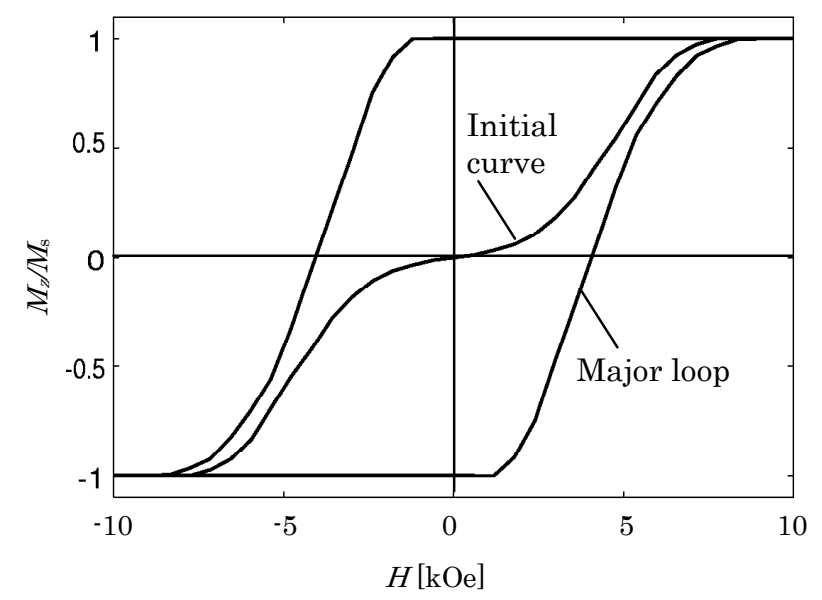

Fig. 2 Hysteresis loop of a perpendicular magnetic film of a slave disk in the perpendicular direction.

\section{3. シミュレーション結果及び考察}

\section{1 ビット転写特性のマスターディスク $M_{s}$ 依存性}

飽和磁化 $490 \mathrm{emu} / \mathrm{cm}^{3}$ のマスターディスクに, $4 \mathrm{kOe}$ の膜面垂 直方向転写磁場を印加した場合に, スレーブディスクに転写され た磁化の垂直成分 $M_{z}$ を Fig. 3 に示寸. 同図の縦軸はスレーブディ スクの飽和磁化 $M_{\mathrm{s}}$ で規格化してある. なお, ここで初期磁化され たマスターディスクの $M_{2} / M_{\mathrm{s}}$ をー1 としている. マスター磁性層 との接触部で磁化が反転し, 非接触部では初期磁化が保存されて いることがわかる.

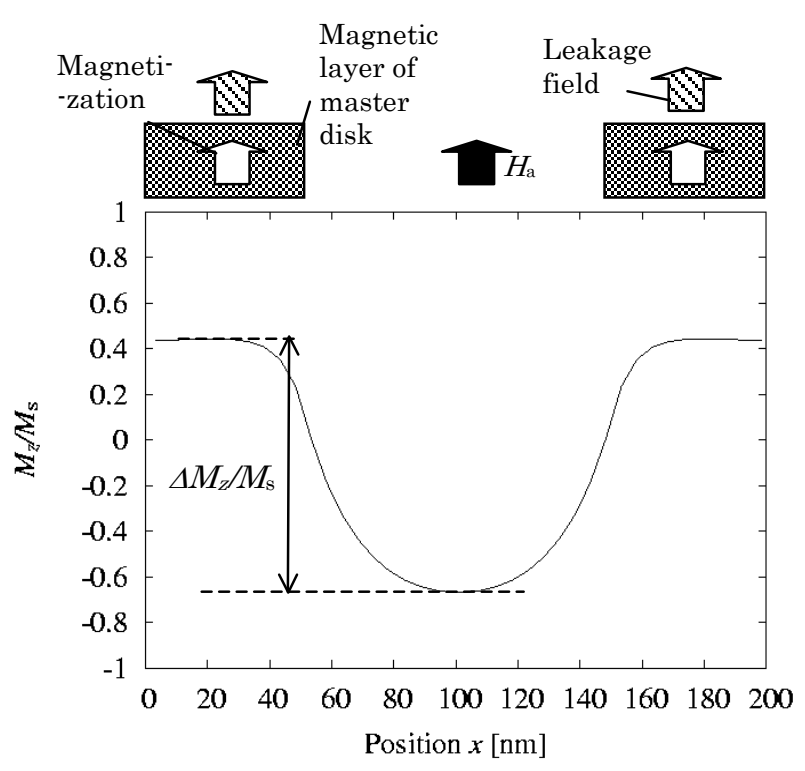

Fig. 3 Magnetization distribution of the slave disk in the case of bit printing with a duplication field of $4 \mathrm{kOe}$ using a master disk with a saturation magnetization of $490 \mathrm{emu} / \mathrm{cm}^{3}$.

マスターディスクの飽和磁化を 490, 1000, 1500, 1900 $\mathrm{emu} / \mathrm{cm}^{3}$ と変えた場合の, スレーブディスクに転写された 磁化の転写磁場依存性を Fig. 4 に示す. 同図の縦軸は, Fig. 3 における磁化の最大值と最小值の差 $\Delta M_{z} / M_{\mathrm{s}}$ である. $\triangle$ $M_{Z} / M_{\mathrm{s}}=2$ のとき, スレーブディスクの磁化が上向き, 下 向きとも飽和していることを示している. なお, $\Delta M_{z} / M_{\mathrm{s}}$ が 大きいほど高い再生出力が得られると考えられるので, 大きな $\Delta M_{Z} / M_{\mathrm{s}}$ ほど転写特性が優れていると言える.

ビット転写において転写磁場は, 従来, スレーブディスクの保磁 力 $(4 \mathrm{kOe})$ 付近が最適と夕なされていた ${ }^{5}$. Fig. 4 から,この最適 転写磁場付近では, 転写特性のマスターディスク $M_{\mathrm{s}}$ 依存性はほと んど見られず, マスターディスクの $M_{\mathrm{s}}$ が $490 \mathrm{emu} / \mathrm{cm}^{3}$ の場合に わずかに劣化する程度であることがわかる.これは, ビット転写で はマスターディスクの反磁場係数が大きいため, マスターディス クが吸収する磁束の量が, マスターディスクの $M_{\mathrm{s}}$ によってほとん ど変わらないためだと推定される (反磁場係数に関しては, 3.4 節 で考察する). しかし，転写磁場を強くすると転写特性のマスター ディスク $M_{\mathrm{s}}$ 依存性が見られる. マスターディスクの $M_{\mathrm{s}}$ が 490 $\mathrm{emu} / \mathrm{cm}^{3}$ と低い場合, 強い転写磁場で転写特性が大きく劣化する. これは, マスターディスクの $M_{\mathrm{s}}$ が低い場合, 転写磁場が強くなる とマスターディスクが飽和寸るために, マスターディスクとの非 接触部における磁化も書き換えられるためである (マスターディ スクの磁化に関しては, 3.3節で考察する). マスターディスクの $M_{\mathrm{s}}$ が高い場合は, 転写磁場を強くしてもマスターディスクは飽和し ないが, マスターディスクとの接触部の磁化は飽和值になり, かつ 非接触部の磁化も書き換えられることにより, 接触部と非接触部 との差が減り転写特性が劣化する. 


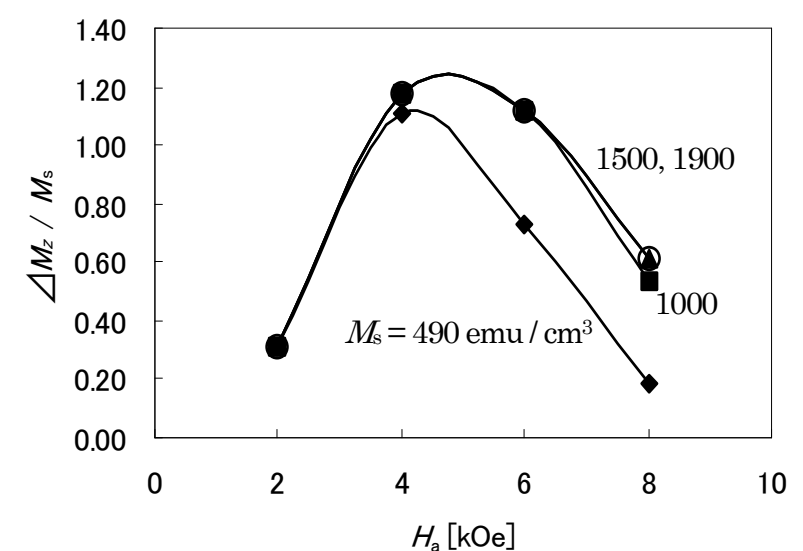

Fig. 4 Dependence of $\Delta M_{Z} / M_{\mathrm{s}}$ on the duplication field $H_{\mathrm{a}}$ in the case of bit printing.

\section{2 エッジ転写特性のマスターディスク $M_{s}$ 依存性}

飽和磁化 $1900 \mathrm{emu} / \mathrm{cm}^{3}$ のマスターディスクに, $4 \mathrm{kOe}$ の面内方 向転写磁場を印加した場合に，スレーブディスクに転写された磁 化の垂直成分 $M_{z}$ を Fig. 5 に示寸. マスター磁生層エッジ部近傍で スレーブディスクが垂直方向に磁化されていることがわかる.

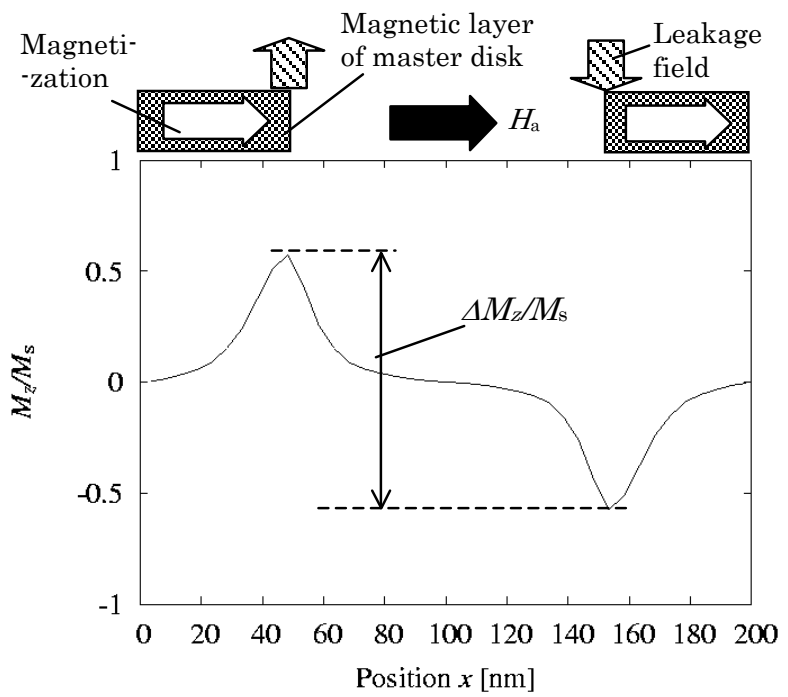

Fig. 5 Magnetization distribution of the slave disk in the case of edge printing with a duplication field of $4 \mathrm{kOe}$ using a master disk with a saturation magnetization of $1900 \mathrm{emu} / \mathrm{cm}^{3}$.

マスターディスクの飽和磁化を 490，1000，1500，1900 $\mathrm{emu} / \mathrm{cm}^{3}$ と変えた場合の, スレーブディスクに転写された 磁化の転写磁場依存性を Fig. 6 に示寸. Fig. 6 から, マスタ ーディスクの $M_{\mathrm{s}}$ が $490 \mathrm{emu} / \mathrm{cm}^{3}$ の場合は, 転写磁場を強 くしても転写特性はほぼ変わらないが， $M_{\mathrm{s}}$ が 1000 $\mathrm{emu} / \mathrm{cm}^{3}$ 以上の場合は, 転写磁場を強くすると転写特性が 向上し飽和する傾向があることがわかる. 飽和する磁場の 值は $M_{\mathrm{s}}=1000 \mathrm{emu} / \mathrm{cm}^{3} よ り も, 1500,1900 \mathrm{emu} / \mathrm{cm}^{3}$ の方 が高い. なお, $M_{\mathrm{s}}=1500$ 及び $1900 \mathrm{emu} / \mathrm{cm}^{3}$ の場合, $H_{\mathrm{a}}$ が $6 \mathrm{kOe}$ 以上で飽和しているのは, $\Delta M_{z} / M_{\mathrm{s}} \fallingdotseq 2$ となり, スレーブディスクの磁化が飽和しているためである. Fig.
4 と Fig. 6 を比較すると, マスターディスクの $M_{\mathrm{s}}$ 依存性は, ビット転写よりもエッジ転写の方が大きい。これは，エッ ジ転写ではビット転写の場合に比べてマスターディスクの 反磁場係数が小さいので，マスターディスクの $M_{\mathrm{s}}$ が大き いほど磁束を吸収する量が増えるためだと考えられる。そ のため, マスターディスクエッジ部から発生する磁場の垂 直成分もマスターディスクの $M_{\mathrm{s}}$ が高いほど強くなり，転 写特性が向上する(反磁場係数に関しては, 3.4 節で考察する).

なお，ビット転写においては $\Delta M_{z} / M_{\mathrm{S}}$ の最大值が 1.2 程 度であるのに対し(Fig. 4), エッジ転写では $\Delta M_{Z} / M_{\mathrm{s}}=2$ が得られている(Fig. 6)。この点から, エッジ転写の方がビ ット転写よりも転写特性が優れていると言える.

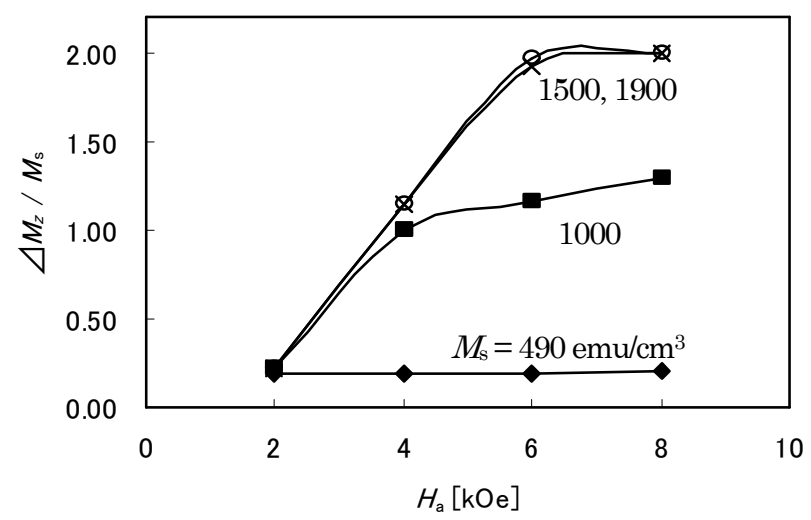

Fig. 6 Dependence of $\Delta M_{z} / M_{\mathrm{S}}$ on the duplication field $H_{\mathrm{a}}$ in the case of edge printing.

\section{3 マスター磁性層の磁化}

3.2 節におけるビット転写及びエッジ転写のマスターデ イスク $M_{\mathrm{s}}$ 依存性の相違の原因を調べるために，まず，マス ターディスクが有する磁性層の磁化を計算した. Figs. 7, 8 に，ビット転写及びエッジ転写におけるマスター磁性層中 心位置の磁化の転写磁場依存性を示寸。これらの図では, マスターディスクの飽和磁化 $M_{\mathrm{s}}$ をパラメータとしている.

Fig. 7 において, 最適転写磁場とみなせるスレーブディ スクの保磁力 $(4 \mathrm{kOe})$ 付近の磁化を見ると, いずれのマス ターディスク $M_{\mathrm{s}}$ においてもほぼ同じ值になっていること がわかる. これより, Fig. 4 において, 最適転写磁場付近の転写特 性がマスターディスクの $M_{\mathrm{s}}$ によってほとんど変わらないのは, マ スターディスクの磁化が $M_{\mathrm{s}}$ によらずほぼ同じ值であり, マスター ディスクに集中する磁束の量が同程度であるためだと考えられる. また, $M_{\mathrm{s}}$ が $490 \mathrm{emu} / \mathrm{cm}^{3}$ の場合, 転写磁場が $4 \mathrm{kOe}$ でマス ターディスクが飽和している.これが, マスターディスク の $M_{\mathrm{s}}$ が $490 \mathrm{emu} / \mathrm{cm}^{3}$ の場合に, 強い転写磁場で転写特性 が大きく劣化する原因である.

Fig. 8 から，マスターディスクの $M_{\mathrm{s}}$ が 490,1000 及び $1500 \mathrm{emu} / \mathrm{cm}^{3}$ の場合, それぞれ 2,4 及び $6 \mathrm{kOe}$ て飽和している ことがわかる. Fig. 6 においては $M_{\mathrm{s}}=1500 \mathrm{emu} / \mathrm{cm}^{3}$ と 1900 $\mathrm{emu} / \mathrm{cm}^{3}$ の差は見られないが, これは, スレーブディスクの保磁 力が $4 \mathrm{kOe}$ であるためであり, より高保磁力のスレーブディスク に対しては $M_{\mathrm{s}}=1900 \mathrm{emu} / \mathrm{cm}^{3}$ の方が優れていることが, Fig. 8 
から予想される. Figs. 7, 8 を比較すると, ビット転写及びエ ッジ転写において, 各転写磁場におけるマスターディスク 磁化の值が異なっているが，これは，マスターディスクの 反磁場が影響しているものと考えられる.この点に関して, 次節でマスター磁性層中の反磁場について考察する.

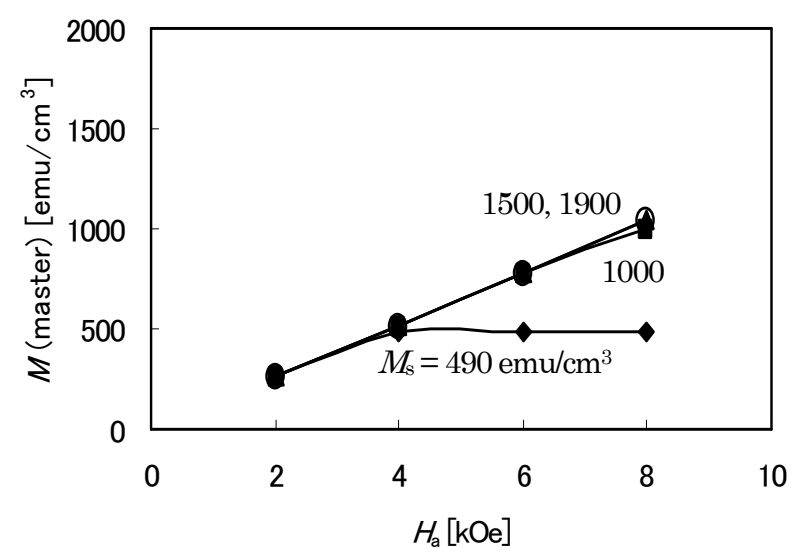

Fig. 7 Dependence of the magnetization at the center of the master disk on the duplication field in the case of bit printing.

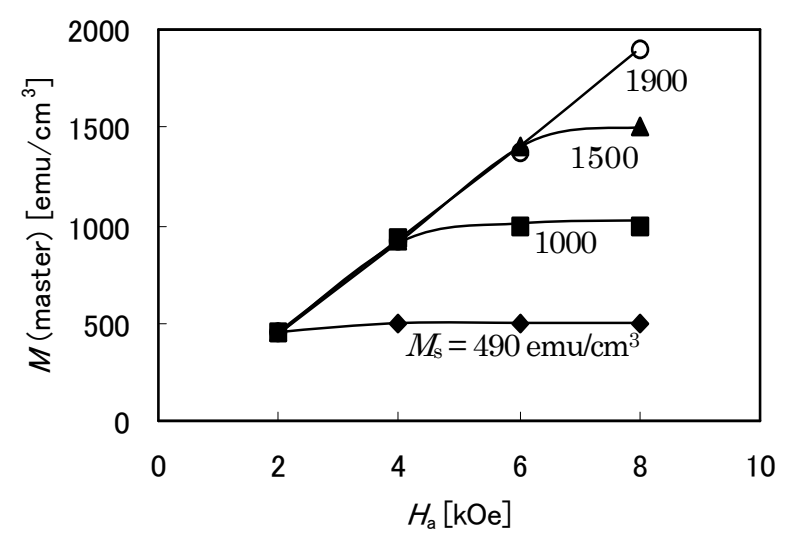

Fig. 8 Dependence of the magnetization at the center of the master disk on the duplication field in the case of edge printing.

\section{4 マスター磁性層中の反磁場}

Figs. 9, 10 に, ビット転写及びエッジ転写におけるマス ター磁性層中の反磁場 $H_{\mathrm{d}}$ のマスターディスク $M_{\mathrm{s}}$ 依存性を 示す.

Figs. 9, 10 から, マスターディスクの $M_{\mathrm{s}}$ が高い場合, 転 写磁場を強くすると反磁場も強くなることがわかる. マス ターディスクの $M_{\mathrm{s}}$ が低い場合には, マスターディスクが 飽和するため, 高転写磁場にしても, 反磁場は強くならな い.

また, ビット転写とエッジ転写を比較すると, 反磁場に 明らかな違いが見られる.この点についてさらに詳細に調 ベるために, 反磁場係数を求めた. Fig. 11 にビット転写及 びエッジ転写におけるマスターディスクの反磁場係数 $N$ を 示す. なお, 反磁場係数 $N$ はマスターディスク中心部にお
ける反磁場を, マスターディスク中心部の磁化の $4 \pi$ 倍で 割ることにより求めた. 反磁場係数 $N$ は, ビット転写では 約 0.59, エッジ転写では約 0.32 である.これより, ビット 転写よりもエッジ転写の方が, 反磁場係数が低い状態で動 作していることがわかる.このことから, ビット転写では 反磁場係数が大きいために, マスターディスクの飽和磁化 の影響は小さく, エッジ転写では反磁場係数が小さいため に, マスターディスクの飽和磁化の影響が大きいと結論付 けられる。

反磁場係数が異なる理由は, 磁場の印加方向にある. ビ ット転写ではマスターディスク媒体膜面垂直方向に磁場を 印加するため, 膜厚方向にはマスター磁性層は一つしかな く, 更に, マスター磁性層が面内方向に無限に広がってい るために, 反磁場係数は大きくなる.一方エッジ転写では, 媒体膜面内方向に磁場を印加するため, 面内方向にはマス ター磁性層が無限に並び, マスター磁性層面内方向端面に 表れる磁極が互いに引き合うため, 全体としてみると反磁 場係数が小さくなる.

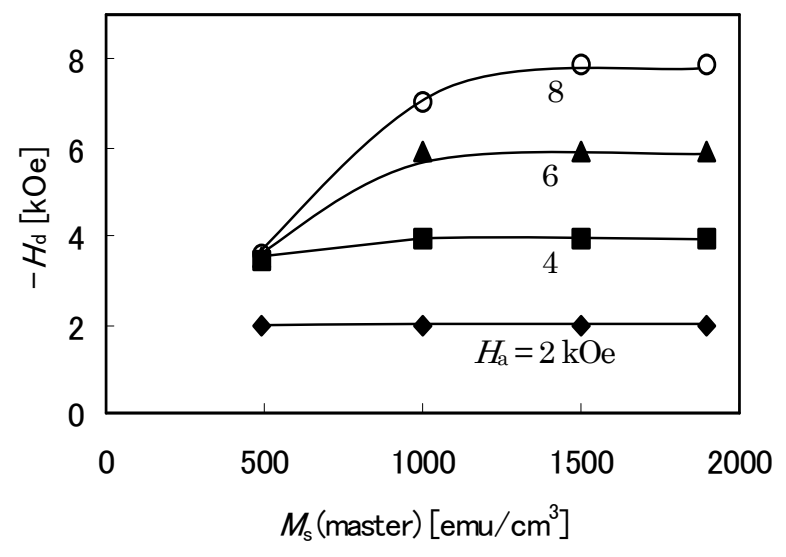

Fig. 9 Dependence of $-H_{\mathrm{d}}$ on the saturation magnetization of the master disk in the case of bit printing.

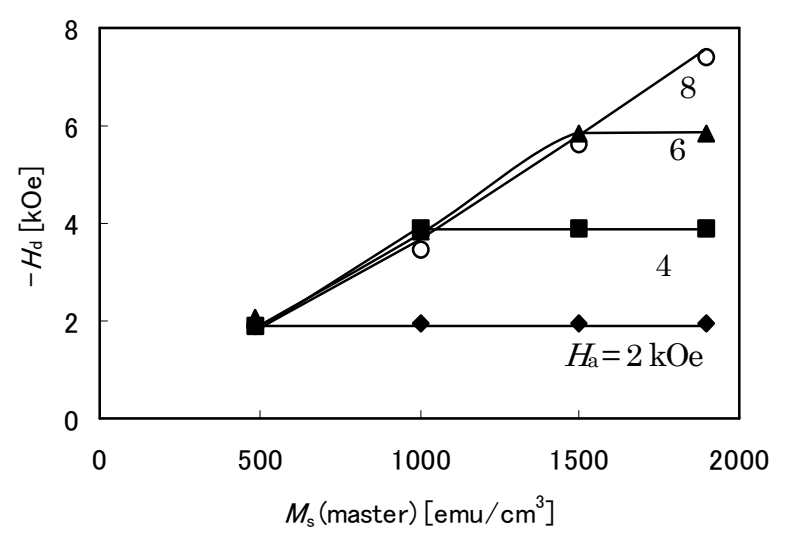

Fig. 10 Dependence of $-H_{\mathrm{d}}$ on the saturation magnetization of the master disk in the case of edge printing. 


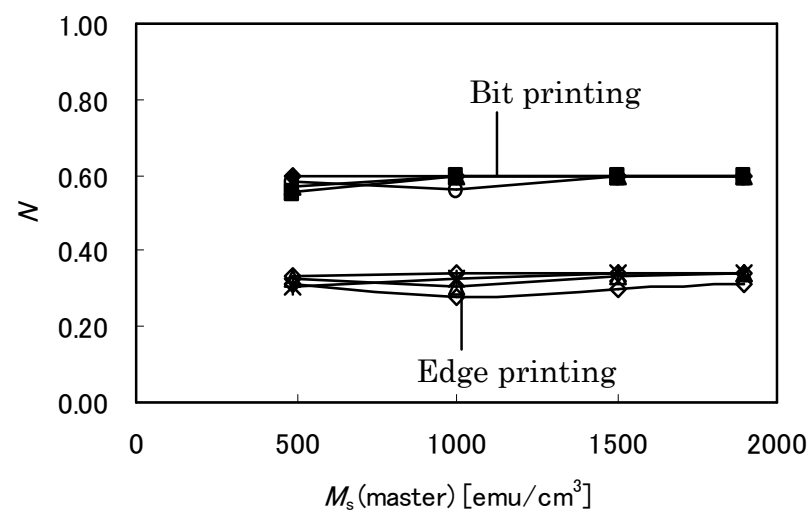

Fig. 11 Demagnetizing field coefficients in the cases of bit printing and edge printing.

\section{5 ビット転写及びエッジ転写の適応性}

ビット転写は，単磁極へッド記録と同様な再生波形であ るため，現状のサーボ信号記録方式を，できるだけ信号処 理系などのドライブ側における変更を少なくして，転写方 式に切り替えることが可能である。一方，エッジ転写は， 再生波形が単磁極へッド記録と異なるので，この方法をサ 一ボ信号記録法として採用するためには，信号処理系の変 更も必要と考えられる.しかし, エッジ転写の方がビット 転写よりも，転写特性が優れているため，より高密度の垂 直ハードディスクに対しては，エッジ転写の方が適してい るものと予想される.

\section{4. まとめ}

垂直磁気記録媒体に磁気転写寸る際に，マスターディス クの飽和磁化が垂直磁気転写特性に与える影響を，2 次元 有限要素法シミュレーションを用いて，ビット転写（媒体 膜面の垂直方向に転写磁場を印加）及びエッジ転写（媒体 膜面の面内方向に転写磁場を印加）に対して検討し，次の ことが明らかになった。

ビット転写において，最適転写磁場とみなせるスレーブ ディスク保磁力 $(4 \mathrm{kOe})$ 付近における転写特性は，マスタ 一ディスクの飽和磁化の影響はほとんど見られない. 一方, エッジ転写においては，マスターディスクの飽和磁化が高 いほど優れた転写特性が得られる。このようにマスターデ イスクの飽和磁化の影響が異なる理由は，マスターディス クの反磁場にあり，ビット転写では反磁場係数が大きいた め飽和磁化の影響が小さく，エッジ転写では反磁場係数が 小さいため，飽和磁化の影響が大きい.

謝辞 本研究の一部は，新エネルギー・産業技術総合開発 機構(NEDO)産業技術研究助成事業, 及び日本学術振興会 科学研究費(基盤研究 C16560291)の支援により行いました. 謝意を表します.また，ご協力，有益なご議論を頂きまし た長尾信氏を始めとする富士フイルム(株)の皆様に深謝致 します。

\section{References}

1) R. Sugita, O. Saito, T. Muranoi, M. Nishikawa and M. Nagao: J. Appl. Phys., 91, 8694 (2002)

2) A. Saito, T. Hamada, T. Ishida, Y. Takano, and E. Yonezawa: IEEE Trans. Magn., 38, 2195 (2002).

3) M. Nishikawa, S. Wakamatsu, K. Ichikawa, T. Usa, M. Nagao, T. Ishioka, T. Yasunaga, T. Komine, R. Sugita: IEEE Trans. Magn., 42, 2612 (2006).

4) A. Saito, T. Ono, and S. Takenoiri: IEEE Trans. Magn., 39 , 2234 (2003).

5) A. Izumi, Y. Nagahama, T. Komine, R. Sugita, and T. Muranoi: J. Magn. Soc. Jpn., 30, 184 (2006)

2006年9月28日受理，2007年1月23日採録 